\title{
Marzena Kutt
}

\section{Pajdokracja w ujęciu Feliksa} Konecznego w kontekście współczesnych form zjawiska

\author{
Paedocracy According to Feliks Koneczny \\ in the Context of Its Modern Manifestations
}

\begin{abstract}
Abstrakt
W artykule podjęto próbę analizy przekonań Feliksa Konecznego na temat pajdokracji w kontekście współcześnie obserwowanych form aktywności politycznej młodzieży. W tym celu zostały omówione wybrane teksty na temat pajdokracji opublikowane przez Konecznego na łamach dziennika "Słowo" w okresie od 16 września do 22 października 1912 r. W tym czasie krakowski uczony napisał: O pajdokracji, Partenogeneza pajdokracji, Pajdokracja z prowokacji, Młodzież jako środek reklamy, Młodzież jako rzekoma rękojmia przyszłości, Pajdokracja i apatia, Stronnictwa a pajdokracja, Brak pajdokracji w Wielkopolsce, Patryjotyzm bez zajęcia oraz Szacunku dla młodzieży. Na podstawie analizy tekstów źródłowych przedstawiono definicję pajdokracji, jej przyczyny oraz skutki. Te informacje zostały zestawione z innymi ujęciami pajdokracji (np. pedagogicznym) oraz z jej współczesnymi obliczami. Koneczny oceniał pajdokrację jednoznacznie negatywnie. Uważał, że jest ona szkodliwa społecznie i wynika z błędnych przekonań. „Rządy młodzieży”, w opinii historiozofa, są inspirowane wyłącznie przez dojrzałych polityków, którzy manipulują młodymi w celu realizacji
\end{abstract}


własnych zamierzeń. Takie postępowanie wynika z braku szacunku dla młodzieży, o który Koneczny wyraźnie zabiega. Badacz dostrzega wiele zalet młodych Polaków, ale równocześnie ma świadomość, że pewne cechy młodości nie są pożądane w polityce (jak brak kompetencji, naiwność, podatność na wpływ czy emocjonalność). Dochodzi do wniosku, że jedynym sposobem zwalczenia pajdokracji mogłoby być całkowite odsunięcie młodych od polityki. Równocześnie zdaje sobie sprawę, że tak radykalne rozwiązanie nie jest możliwe. W swoim wywodzie Koneczny nie tylko opisuje wady pajdokracji, ale również wskazuje, jak można z nią walczyć.

Słowa klucze: Feliks Koneczny, młodzież, pajdokracja, polityka

\section{Abstract}

The article attempts to analyze Feliks Koneczny's beliefs about paedocracy in the context of presently observed forms of youth political activity. For this purpose, the paper offers a discussion of selected texts on paedocracy published by Koneczny in the Stowo daily between September 16 and October 22, 1912. At that time, Koneczny wrote: O pajdokracji [On Paedocracy], Partenogeneza pajdokracji [Partenogenesis of Paedocracy], Pajdokracja z prowokacji [Provoked Paedocracy], Młodzież jako środek reklamy [Youth as a Means of Advertising], Młodzież jako rzekoma rękojmia przyszłości [Youth as the Supposed Guarantor of the Future], Pajdokracja i apatia [Paedocracy and Apathy], Stronnictwa a pajdokracja [Parties and Paedocracy], Brak pajdokracji w Wielkopolsce [No Paedocracy in Greater Poland], Patryjotyzm bez zajęcia [Jobless Patriotism] and Szacunku dla młodzieży [Respect Youth]. Based on the analysis of source texts, the definition of paedocracy is presented on to of its causes and effects. This information is juxtaposed with other takes on paedocracy (e.g., in education) and its contemporary faces. Koneczny's assessment of paedocracy was unequivocally negative. He believed it was socially harmful and resulted from a number of misconceptions. "Youth rule," in the scholar's view, is inspired solely by mature politicians who manipulate the young to achieve their own agendas. Such behavior stems from the lack of respect for youth that Koneczny clearly sought. The researcher saw many advantages of young Poles, but at the same time he was aware that some features of youth are not desirable in politics (such as lack of competence, naivety, susceptibility to influence or emotionality). He concluded that the only way to combat paedocracy might be to remove the young from politics altogether. At the same time, he realized that such a radical solution was not possible. In his argument, Koneczny not only described the flaws of paedocracy, but also showed how it can be combatted.

Keywords: Feliks Koneczny, youth, paedocracy, politics 
W życie polityczne coraz częściej angażują się osoby bardzo młode. Dość wspomnieć, że w 2015 r. najmłodszy poseł miał 23 lata, natomiast 17 innych nie ukończyło 30 r.ż. Portal wyborcza.pl przytacza słowa jednej z tych osób, 25-letniej doktorantki będącej od 18 r.ż. członkiem PO: „Młodzi powinni wziąć sprawy w swoje ręce. Dlaczego ktoś ma nam urządzać życie?"'. Do innych form udziału młodzieży w polityce należą różnego rodzaju rady ${ }^{2}$, zrzeszenia, organizacje i subkultury, przykładowo Młodzież Wszechpolska ${ }^{3}$. Poza tym młodzi biorą udział w szeregu wydarzeń związanych z polityką - manifestacjach, demonstracjach, marszach, protestach, wiecach itd. Nie zawsze tego typu działania są podejmowane przez młodych tylko z własnej motywacji, mogą one być również skutkiem propagandy politycznej mającej na celu aktywizację młodzieży, co w dalszej kolejności ma się przyczynić do sukcesu konkretnej osoby bądź grupy.

Chociaż liczne przykłady wskazują na zaangażowanie i aktywność polityczną młodzieży, jest ona często opisywana jako bierna i separująca się od działalności społecznej. Jak twierdzi Messyasz, nie należy oczekiwać wzrostu udziału młodych w sferze publicznej z uwagi na apolityczność i indywidualizm tej grupy społecznej. Deficyt odpowiedniej edukacji obywatelskiej w domu, mediach oraz szkole przekłada się w opinii badaczki na nieumiejętność korzystania z mechanizmów demokratycznych. Znaczący jest również niedobór komunikatów politycznych skierowanych do młodych (nieadekwatny język, brak propozycji programowych). Wśród potencjalnych długofalowych konsekwencji takiego stanu rzeczy Messyasz wskazuje braki wspólnotowego instrumentarium

1 https://wyborcza.pl/7,75398,19145772,piekni-20-letni-w-sejmie-kim-sa-najmlodsi-poslowie.html (dostęp: 14.11.2021).

2 Za przykład może posłużyć powołana pierwszy raz w 2016 r. Rada Dzieci i Młodzieży Rzeczypospolitej Polskiej przy Ministrze Edukacji i Nauki. Zadanie organu zdefiniowano jako „wyrażanie opinii, w tym przedstawianie propozycji w kwestiach dotyczących dzieci i młodzieży w zakresie spraw objętych działem administracji rządowej oświata i wychowanie, w szczególności przedstawianie opinii na temat planowanych zmian, w tym propozycji rozwiązań". Największe zainteresowanie członkostwem w Radzie odnotowano w 2020 r. Swoją kandydaturę zgłosiło wówczas 331 młodych osób, spośród których wyłoniono 16 członków Rady i 16 zastępców. Za: Zarządzenie Ministra Edukacji i Nauki z dnia 7 grudnia 2020 r., https://www.infor.pl/akt-prawny/ U20.2020.012.0000018,zarzadzenie-ministra-edukacji-i-nauki-w-sprawie-powolania-rady-dzieci-i-mlodziezy-rzeczypospolitej-polskiej-przy-ministrze-edukacji-i-nauki. html; https://www.gov.pl/web/edukacja-i-nauka/powolano-rade-dzieci-i-mlodziezy-rzeczypospolitej-polskiej-przy-ministrze-edukacji-i-nauki (dostęp: 14.11.2021).

3 Weronika Bartoszewicz, „Nacjonalizm na przykładzie Młodzieży Wszechpolskiej”, Biuletyn Kryminologiczny 26 (2019): 161-175. 
symbolicznego, ucieczkę w prywatność oraz narastający dystans dzielący elity polityczne i resztę społeczeństwa ${ }^{4}$. Jak twierdzi:

Młodzi [...] mobilizują się rzadko i zazwyczaj w wyjątkowych okolicznościach [...]. Styl dyskursu polityki i dyskursu politycznego skutecznie zniechęcają do czynnego interesowania się sprawami publicznymi, przyczyniając się do postrzegania sporów nie jako immanentnej reguły demokracji, ale jako zjawiska negatywnego ${ }^{5}$.

W tym miejscu należałoby podjąć refleksję - czy dążenie do ciągłego zwiększenia czynnego udziału młodych w polityce jest uzasadnione? Czy młode osoby mają wystarczające doświadczenie i wiedzę, by móc wpływać na losy państwa? A jeżeli już młodzież miałaby się angażować w życie publiczne, to w jakiej formie? Wskazane problemy nie są nowe. Refleksję nad tymi zagadnieniami podjął już w 1912 r. Feliks Koneczny ${ }^{6}$ w serii artykułów poświęconych zjawisku pajdokracji.

Na zbiór O pajdokracji składają się artykuły opublikowane przez Konecznego w dzienniku „Słowo” w okresie od 16 września do 22 października 1912 r. Są to kolejno: O pajdokracji, Partenogeneza pajdokracji, Pajdokracja z prowokacji, Młodzież jako środek reklamy, Młodzież jako rzekoma rękojmia przyszłości, Pajdokracja i apatia, Stronnictwa a pajdokracja, Brak pajdokracji w Wielkopolsce, Patryjotyzm bez zajęcia oraz Szacunku dla młodzieży. Autor ukazuje problem z bardzo szerokiej perspektywy, oceniając go w sposób jednoznacznie negatywny. Dla krakowskiego badacza pajdokracja jest niczym innym jak chorobą toczącą społeczeństwo. Chociaż od czasu powstania tekstów minął już ponad wiek, obserwacje krakowskiego uczonego można z łatwością odnieść do bieżących wydarzeń.

4 Karolina Messyasz, „Rola i znaczenie polityki w świecie młodych ludzi. Perspektywa transformacyjna”, Władza Sązenia 1: 134.

5 Ibidem.

6 Feliks Koneczny, historiozof znany przede wszystkim za sprawą teorii wielości cywilizacji, urodził się w 1862 r. w Krakowie. W 1920 r. został mianowany profesorem nadzwyczajnym, a dwa lata później profesorem zwyczajnym w Uniwersytecie Stefana Batorego. Dramat II wojny światowej boleśnie dotknął Konecznego chociażby za sprawą śmierci synów i synowej. Po wojnie nie było mu dane kontynuować kariery akademickiej, chociaż starał się o pracę w Uniwersytecie Jagiellońskim. Ostatnie lata życia wypełnił działalnością publicystyczną. Zmarł w 1949 r. Za: Ryszard Polak, „Feliks Koneczny. Biografia uczonego", Człowiek w Kulturze 10 (1998): 161-173. 


\section{Młodzież - próba zdefiniowania}

Przede wszystkim młodość nie jest jedynie okresem uwarunkowanym zmianami biologicznymi, ale stanowi, zdaniem Tillmanna, zjawisko społeczno-kulturowe podlegające wymiarom historyczno-społecznym ${ }^{7}$. $Z$ tego powodu trudno jest wskazać jednoznaczną, uniwersalną definicję tego pojęcia. Przykładowo Hajduk dostrzega trzy aspekty opisujące młodzież. Zdaniem badacza jest to: 1) kategoria społeczna; 2) wielka grupa społeczna; 3) pokolenie ${ }^{8}$.

Chociaż podstawowe kryterium przynależności do grona młodzieży to wiek, nie jest on warunkiem wystarczającym ${ }^{9}$. Zresztą kryterium wieku nastręcza pewnych trudności. O ile moment wkroczenia do społeczności młodzieży można wskazać stosunkowo precyzyjnie (ok. 13 r.ż), o tyle wiek, w którym się ją opuszcza i staje dorosłym, nie jest już taki oczywisty. Tillmann szacuje, że przypada on na okres pomiędzy 20 a 30 r.ż. Warto zauważyć, że wskazany przedział pokrywa się niemal w zupełności z wyodrębnionym przez Arnetta odrębnym etapem życia, który badacz nazwał stającą się dorosłością ${ }^{10}$.

Osoby w tej fazie przejściowej poświęcają czas na poznawanie możliwych kierunków aktywności życiowej i dokonują intensywnej eksploracji, przede wszystkim w obszarze związków intymnych, pracy i ideologii ${ }^{11}$,

a z pewnością również poglądów politycznych. Przesunięciu granicy, po której następuje dorosłość, towarzyszy zróżnicowanie dróg życiowych młodych, co także nie ułatwia wskazania, kiedy dokładnie kończy się przynależność do grona młodzieży ${ }^{12}$.

Biorąc pod uwagę charakterystyki demograficzne, osoby wchodzące w dorosłość cechuje zróżnicowanie w zakresie: 1) związków intymnych

7 Hartmut M. Griese, Socjologiczne teorie młodzieży (Kraków: Oficyna Wydawnicza Impuls, 1996), 11.

8 Barbara Hajduk, Socjalizacja studentów. Badania panelowe studentów z Zielonej Góry (Warszawa: Wydawnictwo Akademickie „Żak”, 2003), 73.

9 Klaus J. Tillmann, Teorie socjalizacji. Społeczność, instytucja, upodmiotowienie (Warszawa: Wydawnictwo Naukowe PWN, 2006).

10 Jeffrey J. Arnett, „Emerging Adulthood. A Theory of Development from the Late Teens through the Twenties", American Psychologist 55/5: 469-480.

11 Anna Brzezińska, Radosław Kaczan, Konrad Piotrowski, Małgorzata Rękosiewicz, „Odroczona dorosłość: fakt czy artefakt?”, Nauka 4 (2011): 67-107.

12 Radosław Marzęcki, Młody obywatel we współczesnej demokracji europejskiej (Warszawa: Dom Wydawniczy ELIPSA, 2013). 
(wolne związki, zmiany partnerów, małżeństwo); 2) posiadania dzieci (są osoby, które już je mają, podczas gdy inne nie posiadają lub nie planują); 3) miejsca zamieszkania (typowe są częste zmiany w tym zakresie; młodzi ludzie mieszkają z rodzicami/opiekunami, w akademikach, stancjach itd.); 4) edukacji (część osób podejmuje studia); 5) aktywności zawodowej (praca na pełny etat, w niepełnym wymiarze godzin, dorywcza; częste zmiany miejsca zatrudnienia) $)^{13}$. Z kolei wśród cech, które są młodzieży wspólne, podaje się przykładowo: 1) brak ukształtowanej świadomości kulturowej, podatność na różne postawy i wartości; 2) inicjatywę, potrzebę zmian, aspiracje nacechowane żywiołowością i emocjami; 3) daleko posunięty krytycyzm wobec dorosłych wynikający z różnic celów i zainteresowań; 4) innowacyjność, niekonwencjonalność w kreowaniu siebie i otoczenia ${ }^{14}$.

Poszukując istoty młodości, przyjęto założenie, że za młodzież należy uznać osoby, które „dopiero przystosowują się do pełnego życia w społeczeństwie"15. Młodzież odracza podjęcie zobowiązań typowych dla dorosłości (małżeństwo, zdobycie zawodu i niezależności finansowej, przyjęcie na siebie odpowiedzialności cywilnej itd.). Zdaniem Marzęckiego takie postrzeganie młodych koresponduje z definiowaniem młodości przez pryzmat pokwitania, więc jedynie w kontekście biologii. Tymczasem w obszarze politologii istotny jest ten „moment, w którym działanie jednostki staje się znaczące dla systemu politycznego, wspólnoty, w której ona żyje - moment, kiedy jednostka uzyskuje podmiotowość prawną i polityczną"16. Badacz określa mianem młodego obywatela jednostkę, która: 1) rozpoczyna pełnoprawny udział we wspólnocie; 2) ustosunkowuje się do systemu politycznego; 3 ) zdobywa pierwsze doświadczenia, podejmuje pierwsze decyzje i wybory. Ten okres, w opinii Marzęckiego, rzutuje na typ kultury politycznej, który obywatel będzie reprezentował w przyszłości ${ }^{17}$.

Hildebrandt-Wypych łączy pojęcie młodości z rozwojem cywilizacyjnym, dominującą kulturą, a przede wszystkim z procesem socjalizacji zachodzącym za sprawą systemu wychowania. Zaznacza, że jest

13 Konrad Piotrowski, Tożsamość osobista $w$ okresie wkraczania $w$ dorosłość. Sytuacja młodych osób $z$ ruchowym ograniczeniem sprawności $i$ ich sprawnych rówieśników (Wielichowo: TIPI, 2013), 27.

14 Andrzej Chodubski, „Młodzież jako przedmiot i podmiot życia publicznego”, w Polityka młodzieżowa Unii Europejskiej, red. Maciej Boryń, Bartosz Duraj, Sylwia Mrozowska (Toruń: Wydawnictwo Adam Marszałek, 2014), 11-12.

15 Ibidem, 13.

16 Ibidem.

17 Ibidem, 14. 
to zjawisko wieloaspektowe - biologiczne, psychologiczne, społeczne i, przede wszystkim, kulturowe ${ }^{18}$. Z kolei Szafraniec podkreśla znaczenie młodzieży. Dochodzi do wniosku, że jest ona

bardzo dobrym punktem odniesienia do obserwacji tego, co dzieje się z całym społeczeństwem. Jest soczewką, w której skupiają się najróżniejsze problemy i napięcia systemu. Jest barometrem zmian i społecznych nastrojów. Sytuacja młodych, ich sposób postrzegania świata, ich aspiracje i dążenia życiowe są miarą zmian, które już się dokonały, i dystansu, jaki jeszcze jest do pokonania. Diagnozy młodzieży w naturalny sposób zmuszają do myślenia o przyszłości, wprowadzają w ten rodzaj praktyki intelektualnej, bez której trudno sobie wyobrazić uprawianie światłej i dalekowzrocznej polityki - są naturalnym punktem odniesienia dla prognoz ${ }^{19}$.

Młodzież miałaby być więc swoistym kompasem służącym wytyczaniu kierunku dalszego rozwoju społeczeństwa.

Natomiast Mannheim postrzega młodzież w kategorii ukrytych zasobów, którymi dysponuje każde społeczeństwo. Od aktywizacji młodych miałaby zależeć witalność danej społeczności. Młodzi odgrywają szczególną rolę, gdy zachodzi konieczność adaptacji do nowych warunków otoczenia ${ }^{20}$. Zgodnie z tym ujęciem, raz jeszcze przywołując opinię Szafraniec, należałoby uznać, że młodzież jest

naturalnym rezerwuarem innowacyjności, wynikającym ze specyfiki rozwojowej tej fazy życia (obejmuje ona szczególną chłonność, wrażliwość, potrzebę określenia „siebie” poprzez odniesienia do ważnych idei i zdarzeń, poczucie własnej „peryferyjności” i marginesowości, połączone z krytycyzmem i refleksyjnością). Młodość jest również naturalnym sprzymierzeńcem zmiany, która - potęgując napięcia - zawsze wyraża zapotrzebowanie na zachowania kreujące nową rzeczywistość. Każda zmiana stwarza więc szanse dla innowacyjności młodych ${ }^{21}$.

18 Dobrochna Hildebrandt-Wypych, „Pokolenia młodzieży - próba konceptualizacji”, Przeglad Pedagogiczny 2 (2009): 105-124.

19 Krystyna Szafraniec, Raport Młodzi 2011 (Warszawa: Kancelaria Prezesa Rady Ministrów, 2011), https://nck.pl/upload/attachments/302470/mlodzi_2011.pdf, 11 (dostęp: 14.11.2021).

20 Karl Mannheim, „The problem of youth in modern society”, w Diagnosis of our time. Wartime essays of a sociologist (London: Kegan Paul, Trench, Trubner \& CO., LTD, 1943).

21 Krystyna Szafraniec, „Raz jeszcze o społecznej roli młodego pokolenia. Konteksty lokalne i globalne", Rocznik Lubuski 37/2 (2011): 11-32. 
Można odnieść wrażenie, że przytoczone wyżej charakterystyki młodzieży ocierają się o idealizację tej grupy społecznej, co z kolei przywodzi na myśl powszechnie obserwowany kult młodości. Jego istotą jest wynoszenie na piedestał młodych, ich elastyczności i otwartości na nowe wyzwania. Młodość postrzegana jest jako cel, do którego należy dążyć, a nie jako przejściowy okres, który musi minąć. Obszarem życia ściśle związanym $\mathrm{z}$ kultem młodości jest życie seksualne. W tym kontekście trwały związek jawi się jako ograniczający. Waloryzowana jest z kolei przyjemność i cielesność. Kult ciała wyraża się w nieustannym dążeniu do idealnego wyglądu za pomocą mody, kosmetyków, operacji plastycznych, nadmiernego wysiłku fizycznego itd. Stąd wniosek, że kult młodości w istocie nie obejmuje wszystkich młodych, a jedynie tych stanowiących wyobrażenie ideału - zdrowych, odnoszących sukcesy, skoncentrowanych na sobie konsumentów. Znamienne jest, że takie spojrzenie na młodość mocno rzutuje na postrzeganie innych grup społecznych. Stanowi swoiste krzywe zwierciadło, przypominające osobom niewpisującym się w założenia kultu młodości o ich niedoskonałościach ${ }^{22}$. Najbardziej wyrazisty przykład stanowi tabu obejmujące starość. Ten okres życia kojarzony jest głównie z niedołężnością i śmiercią (a nie z doświadczeniem i życiową mądrością), więc mówienie o nim jest niepożądane ${ }^{23}$.

Na potrzeby artykułu założono, przyjmując kryterium ONZ, że pod pojęciem szeroko rozumianej młodzieży mieszczą się młodzi ludzie w wieku od 15/16 do 30 r.ż. Nie jest to więc jedynie młodzież rozumiana jako adolescenci, ale większa grupa osób o ograniczonej możliwości samostanowienia, wciąż jeszcze kształtująca swoje poglądy na wiele aspektów życia, nadal poszukująca swojej ścieżki życia i dojrzewająca do podjęcia zobowiązań łączonych z dorosłością. Chociaż, podążając za wskazaniami Marzęckiego, być może należałoby przesunąć dolną granicę do poziomu 18 lat, zasadne wydaje się zaliczenie w ramy młodzieży również osób młodszych. Ostatecznie również bardzo młodzi członkowie społeczeństwa mogą interesować się szeroko pojętą polityką i podejmować próby aktywnego wpływania na jej kształt (jak Greta Thunberg, która w momencie rozpoczęcia działalności miała 16 lat). Brak pełni praw obywatelskich nie musi stanowić przeszkody do podejmowania form aktywności politycznej innych niż wybory. Zaliczyć można do nich m.in.

22 Josef Smolík, „Youth and the cult of youth?”, Kultura - Społeczeństwo - Edukacja 1/5 (2014): 203-212.

23 Anna Dąbrowska, „Zmiany obszarów podlegających tabu we współczesnej kulturze”, Język a Kultura 20 (2008), 187. 
udział w demonstracjach, marszach i protestach. Poza tym praktykowane są aktywności nielegalne, jak blokady dróg, niszczenie cudzej własności czy okupacja budynków publicznych ${ }^{24}$.

Opisana wyżej aktywność polityczna nie jest jedyną dostępną drogą uczestnictwa w życiu politycznym. Wyróżniane jest również tzw. zaangażowanie, czyli zainteresowanie polityką. Znajduje ono swój wyraz w postawach wobec podmiotów politycznych - opcji, partii, konkretnych polityków itd. Jak pisze Lubik-Reczek, „szersze spektrum zaangażowania oznacza dogłębną wiedzę o polityce, formacie sceny politycznej, programach konkretnych ugrupowań czy sprecyzowane preferencje wyborcze"25. Przy czym kwestia tak rozumianego zaangażowania nie będzie rozwijana w artykule. Wywód dotyczyć będzie raczej czynnego udziału młodzieży w życiu politycznym, czyli pajdokracji.

\section{O pajdokracji}

Pajdokracja (gr. país, paidós - dziecko i kratós - władza), w najogólniejszym sensie tego słowa, oznacza władzę osób młodocianych ${ }^{26}$. Władzę tę można różnorodnie interpretować, co skutkuje różnicami w definiowaniu zjawiska na kanwie różnych dziedzin nauki. Przykładowo rozumienie pajdokracji proponowane przez pedagogów różni się od tego obowiązującego w obszarze nauk o polityce. Dlatego tak istotne jest rozpoczęcie analizy rozważań Konecznego od doprecyzowania, jak definiuje on pajdokrację. Autor jednoznacznie wskazuje, że są to „rządy młodzieży, a przynajmniej udział jej w rządzach" ${ }^{27}$. Chodzi więc o stosunkowo wąski obszar znaczeniowy. Nie obejmuje on chęci wywierania wpływu na życie społeczności czy edukacji politycznej młodzieży, a jedynie rzeczywiste oddziaływania młodych w obszarze polityki. Jak ujmuje rzecz Koneczny, jest to „występowanie z programami działania i to skuteczne, tak, iż młodzież przeprowadza swą wolę w polityce narodowej”28.

Dla porównania, w ujęciu pedagogicznym pajdokracja jest jednym z typów stosunków mogących łączyć osoby dorosłe i dzieci. Śliwerski

24 Natasza Lubik-Reczek, „Przebudzenie młodego pokolenia. Aktywność polityczna młodzieży - studium przypadku", Przegląd Prawa Konstytucyjnego 2 (2021), 68.

25 Ibidem, 69.

26 Adam Łukaszewicz, „Kilka uwag o pisowni wyrazów greckich (i niektórych innych) w polskich tekstach dotyczących starożytności klasycznej i archeologii", Studia i Materialy Archeologiczne 14 (2009): 105-117.

27 Feliks Koneczny, O pajdokracji (Warszawa: Wydawnictwo „Słowa”, 1912), 3.

28 Ibidem, 4. 
nazywa relacją „pajdokratycznie toksyczną" taki układ sił, w którym dziecko jest „bytem bardziej niż dorosłym”29. W ten sposób młodzi ludzie przeistaczają się w toksycznych władców swoich rodziców, przejmując "panowanie” nad otoczeniem. Z kolei rodzicom zostaje przypisana rola niedojrzałego dziecka ${ }^{30}$. Równocześnie Śliwerski dostrzega możliwość istnienia pozytywnego, uspołecznionego wariantu pajdokracji. Jak twierdzi, wyraża się on w młodzieżowych wspólnotach i komunach, a także w idei republik dziecięcych.

Historia już dowiodła, że dzieci potrafią same stworzyć społeczność, w której pojawi się autonomiczny system samowychowawczy. W jego ramach kreują one środowisko swojego życia, które eliminuje dominację nad nimi ludzi dorosłych. W republice dziecięcej nie ma znaczenia, że dzieci mniej wiedzą, mniej potrafią i mają mniejsze doświadczenie niż dorośli [...]. One dystansują się od dorosłych, korzystając jednak z ich doświadczeń czy wiedzy ${ }^{31}$.

Autor przywołuje utopijną wizję republiki dziecięcej, gdzie akty kryminalne niemal się nie zdarzają, nie ma osób chorych psychicznie, jak również samobójstw. Natomiast dorośli, chociaż są potrzebni w charakterze pomocników, nie mają prawa głosu ${ }^{32}$.

Ciekawy kontekst dla przytoczonych wyżej znaczeń może stanowić twórczość Janusza Korczaka. Na szczególną uwagę zasługuje powieść Król Maciuś Pierwszy (1923), której dziecięcy bohater po śmierci ojca zostaje obwołany królem. Warto również pochylić się nad utworem Kajtuś Czarodziej (1933) obrazującym porywczego urwisa i buntownika. Slany charakteryzuje głównego bohatera, Kajtusia, słowami: „Funkcjonuje jako groźny demagog, obdarzony "władzą terroryzującą", sprawuje rządy totalitarne i dokonuje symbolicznego «linczu na dorosłych» [...]. Jest przykładem pajdokracji ciemnej, groteskowej"33. Bohater marzy o zostaniu czarodziejem, co popycha go w świat wyobraźni, inny od rzeczywistego. Pragnie obalić reguły ustanowione odgórnie przez dorosłych w imię

29 Bogusław Śliwerski, „Prawo dziecka do swoich praw”, Pedagogika Społeczna XVI/4 (2017), 42.

30 Bogusław Śliwerski, „Prawo dziecka do swoich praw”, w Prawa dziecka wczoraj, dziś i jutro - perspektywa korczakowska, red. Marek Michalak (Warszawa: Biuro Rzecznika Praw Dziecka, 2018), 93-141.

31 Śliwerski, „Prawo dziecka do swoich praw”, Pedagogika Społeczna XVI/4 (2017), 54.

32 Ibidem.

33 Katarzyna Slany, „Subwersywne zabawy Kajtusia Czarodzieja”, Pedagogika Przedszkolna i Wczesnoszkolna 1/ 3 (2014), 109. 
nowego porządku opartego na zasadach stworzonych przez dzieci ${ }^{34}$. Kajtuś wydaje się trafną metaforą części młodych, którzy wkraczają w świat polityki w imię burzenia zastanego ładu społecznego narzuconego przez innych, „starszych”; w imię rewolucji. Pozornie tego typu destrukcyjne działania wynikają wyłącznie z inicjatywy owych buntowników, jednak Koneczny ma na ten temat inne zdanie. Ściąga odpowiedzialność z barków młodych ludzi, w jego mniemaniu naiwnych i podatnych na wpływ, i obarcza nią doświadczonych, dojrzałych polityków.

Pajdokrację związaną tylko z polityką Koneczny ocenia jako jednoznacznie szkodliwą. Nie dostrzega żadnych możliwych pozytywnych konsekwencji zjawiska. Wielokrotnie podkreśla, że pajdokracja jest inspirowana przez starsze pokolenia. Obarczanie winą młodzieży jest jego zdaniem zupełnie niesłuszne. Uczony uważa, że młodzi ludzie nie są w stanie samodzielnie narzucać społeczeństwu programów politycznych oraz nie posiadają „kompetencji politycznej”. Stanowią jedynie narzędzie w rękach decydentów, którzy wykorzystują zapał i energię młodzieży do realizacji własnych doraźnych zadań. Osiąganie dalekosiężnych celów za pomocą agitacji młodych pokoleń jest niemożliwe w opinii Konecznego. Co nie zmienia faktu, że środowisko polityczne od lat niezmiennie na to liczy ${ }^{35}$.

\section{Partenogeneza pajdokracji}

W tekście pt. Partenogeneza pajdokracji Koneczny doprecyzowuje myśli ujęte w artykule O pajdokracji. Raz jeszcze zaznacza, że jego zdaniem formacje tworzone samodzielnie przez młodzież akademicką nie mają żadnej przyszłości. Obowiązki studenckie, następnie zawodowe, a także migracja stanowią zdaniem historiozofa skuteczne przeszkody. Chcąc poprzeć swoją tezę przykładem, Koneczny przypisuje podtrzymywanie tradycji uniwersyteckich jedynie gremium profesorów. Pisze:

Skoro niemożliwem jest utrzymanie tradycji wśród młodzieży (o własnych siłach), niemożliwą jest ciągłość działania, a przez to samo działalność młodzieży nie może nigdy osiągnąć tego stopnia napięcia i siły, żeby wywierać wpływ na społeczeństwo, a cóż dopiero rządzić niem ${ }^{36}$.

34 Ibidem.

35 Koneczny, O pajdokracji.

36 Ibidem. 
Badacz podkreśla, że znaczna część społeczności studenckiej nie jest zainteresowana pajdokracją lub wprost ją odrzuca. Tym samym Koneczny wraca do tezy, zgodnie z którą inicjatorami pajdokracji nie są ludzie młodzi, ale starsi. Oparcie się na zapale i energii młodych pokoleń jest dla tego typu polityków, jak twierdzi autor, wyjątkowo komfortowe i bezpieczne. „Bo też, co to za wygoda, mieć parawan z młodzieży, nią się wyręczać, kryć się za nią - w razie pomyślnym wyróść na jej głowach na wielkiego człowieka, w niepomyślnym zaś - zganić na młodzież..." ${ }^{37}$.

\section{Pajdokracja z prowokacji}

W kolejnym tekście Koneczny opisuje podatność młodych na określone treści, przede wszystkim pochlebstwa. Badacz zwraca uwagę, że aby osiągnąć swoje cele i zdobyć poparcie młodzieży, politycy podkreślają jej wyjątkowość, nieograniczony potencjał i siłę sprawczą („Starsi tego nie zrobią, nie zdobędą się na to; ale wy, młodzi, na pewno tego dokonacie" ${ }^{38}$ ). W tej kwestii od czasów Konecznego nie zmieniło się właściwie nic, o czym świadczą wypowiedzi współczesnych polityków, np. „Nam chodzi o to, żeby zrobić miejsce dla was, młodych”, „Waszą siłą jest brak kompleksów i to wy sami wyznaczycie sobie swą rolę"39 czy „Tu przyjechaliście wy, młodzi. I wy jesteście przyszłością" ${ }^{30}$. Pierwsze dwa z zacytowanych zdań padły podczas wydarzenia Campus Polska, którego cel został nakreślony następująco przez jednego ze współpracowników prezydenta Warszawy Rafała Trzaskowskiego: „Młodzi ludzie w Polsce są na wielu poziomach bardzo zaangażowani. Ale nie przekłada się to na politykę. Chcemy to zmienić" ${ }^{11}$. W tym miejscu warto przytoczyć obserwację Konecznego, zgodnie z którą w interesie różnych grup wpływu leży wzmacnianie udziału środowisk młodzieżowych w życiu politycznym.

Odpowiednia nomenklatura wynosząca młodych na piedestał, zdaniem Konecznego, jest przyjmowana przez odbiorców przychylnie i nie wzbudza podejrzeń. „Młodzież, zgromadzona licznie, młodzież-tłum, jest przede wszystkiem zachwycona swoją młodością. Jest to estetycznie

37 Ibidem, 16.

38 Ibidem, 18.

39 https://www.polityka.pl/tygodnikpolityka/kraj/2132068,1,zwiazki-partnerskie-godka-i-aborcja-tusk-i-trzaskowski-w-ogniu-pytan-od-mlodziezy.read (dostęp: 14.11.2021).

40 https://prawo.money.pl/aktualnosci/wiadomosci/artykul/kaczynski;dosyc;szpanu;pot rzebna;jest;nowa;wladza,200,0,849352.html (dostęp: 14.11.2021).

41 https://www.rp.pl/polityka/art8594851-ruch-w-strone-mlodych-rafala-trzaskowskiego (dostęp: 14.11.2021). 
nadzwyczaj piękne, nieraz nawet wzniosłe a moralnie zdrowe"42. Chociaż tego typu entuzjazm ma pozytywny wydźwięk, bywa wzbudzany i wykorzystywany do realizacji celów, które często nie dają się określić jako szczytne czy moralne. Osoby uciekające się do podobnych zabiegów Koneczny określa mianem „pochlebców-uwodzicieli”, a instrumentalnie stosowane peany na cześć młodzieży uznaje za szyderstwo z młodych adresatów. Przyznaje, że młodość rządzi się swoimi prawami, więc zwalczanie pajdokracji argumentacją płynącą z racjonalności typowej dla starszych pokoleń jest z góry skazane na porażkę. Wygrana zawsze przypadnie w udziale wywodom opartym na emocjach.

Historiozof postrzega rozumowanie osób młodych jako naiwne, ale równocześnie elastyczne, żywe, cięte i dosadne. Na korzyść młodzieży działa dynamika argumentacji, jej szybkość i nieprzewidywalność. Co więcej - próby wpłynięcia na przekonania młodych ludzi za pomocą rozsądku mogą poskutkować efektem odwrotnym od zamierzonego. Nie tylko zniechęcą rozmówców do zmiany zdania, ale wręcz doprowadzą do utwierdzenia ich w dotychczasowych przekonaniach. Na marginesie warto zauważyć, że rzeczywiście dla młodzieży typowy jest opór psychologiczny zmierzający do podtrzymania własnej autonomii i stanowiący odpowiedź na różnego rodzaju naciski społeczne. Warto dodać, że z wiekiem tendencja do oporu maleje $e^{43}$.

W toku dyskusji, jak wskazuje Koneczny, większość dotychczasowych oponentów młodzieży dojdzie do wniosku, że być może mają oni rację, a w końcu przyzna im ją w zupełności. Aprobata bierna przeistoczy się w czynną, a zwycięstwo przypadnie młodym. Jedynym remedium mogłoby się okazać zdecydowane i całkowite odsunięcie od polityki osób niedojrzałych i niekompetentnych, więc przede wszystkim zbyt młodych. To radykalne rozwiązanie, zdaniem krakowskiego uczonego, oznaczałoby koniec pajdokracji. Rzecz w tym, jak twierdzi Koneczny, że próby wprowadzenia go w życie niezmiennie skutkują gwałtowną reakcją młodszych pokoleń broniących swojego prawa do udziału w polityce. Co za tym idzie, pajdokracja pozostaje niezagrożona.

42 Koneczny, O pajdokracji, 19.

43 Anna Rokowska, „Opór psychologiczny młodzieży: rola źródła i kierunku presji społecznej w kwestii ujednolicenia ubioru w szkole”, Psychologia Rozwojowa 13/2 (2008): $47-56$. 


\section{Młodzież jako środek reklamy}

Koneczny opisuje również sytuacje, gdy młodzież jest wykorzystywana w charakterze reklamy (a właściwie propagandowej tuby). Badacz jest przekonany, że do tego typu zabiegów uciekają się politycy o ograniczonych możliwościach, bez charyzmy niezbędnej, by pociągnąć za sobą społeczeństwo, za to z olbrzymimi aspiracjami. „Bywa to zawsze człowiek zdolności miernych, ale za to nieograniczonej ambicji”"44. Tymczasem młodzież potrzebuje wielkich ludzi, za którymi mogłaby podążać. Gdy już na horyzoncie pojawi się ktoś chcący uchodzić za taki autorytet, może za sprawą młodych zyskać szeroki rozgłos. Tego typu działania Koneczny ocenia jako moralnie wątpliwe, a stosującym je politykom zarzuca „zarozumiałość i warcholstwo" 45 . Stwierdza: „Człowiek wielki bywa skromnym" ${ }^{46}$, nie stara się szukać popularności wśród młodzieży, nie narzuca się. Może mieć nadzieję na zrozumienie przez młodych, ale nie w chwili obecnej, a dopiero po latach, gdy dojrzeją i będą w stanie adekwatnie ocenić jego propozycje.

Autor dochodzi do wniosku, że osoby szukające poklasku wśród młodszych mają w zanadrzu jedynie idee, których poziom jest zbyt niski dla osób dojrzalszych. Obrazując postać pajdokraty, Koneczny pisze: „pomysł jego stoi niżej przeciętnego współczesnego wykształcenia politycznego, na poziomie na wpół dziecinnym" ${ }^{47}$. To natomiast ma świadczyć o niskim poziomie samego polityka-pajdokraty. Zdaniem krakowskiego badacza pajdokracja pośrednia wpływa ujemnie na polityczny rozwój i wykształcenie społeczeństwa.

Programy najsłabsze, dla narodu najgorsze, a często fatalne - bywają najgłośniej reklamowane i w danym razie mogą się nawet wybić na pierwszy plan samem krzykactwem, oszałamiając ogół, zagłuszając rozumniejszych, lecz mniej biegłych we wrzasku ${ }^{48}$.

Wszystko to dzięki entuzjazmowi, żywiołowości i bezinteresowności młodych ludzi optujących za określonym stronnictwem politycznym. Sytuację może zmienić przede wszystkim sama młodzież, odżegnując się od udziału w tego pokroju praktykach - konkluduje Koneczny.

44 Koneczny, O pajdokracji, 23.

45 Ibidem, 25.

46 Ibidem.

47 Ibidem, 26.

48 Ibidem, 28. 


\section{Młodzież jako rzekoma rękojmia przyszłości}

W kolejnym artykule pt. Młodzież jako rzekoma rękojmia przyszłości Koneczny raz jeszcze dyskredytuje przekonanie, że „kto trzyma w ręku młodzież, ten rozporządza przyszłością" ${ }^{49}$. Wskazuje, że istnieje jeszcze inny szkodliwy społecznie przesąd. Zgodnie z nim szkoła jest obszarem polityki (Die Schule ist ein Politikum). Tymczasem, w opinii badacza, szkolnictwo oddziałuje na poziom umysłowy społeczeństwa, ale „na kierunek umysłowy nie wpływa niemal całkiem i stanowi do tego istne zero wobec potęgi innych wpływów" "50. Zdaniem Konecznego znikoma część społeczeństwa wyraża w dorosłości te same poglądy, którym hołdowała w młodości. Po chwilowej fascynacji następuje refleksja, która często prowadzi do odrzucenia wcześniej wyznawanej idei. Jedynie te osoby, które nie podejmą się trudu krytycznego myślenia, mogą nadal podążać za znaną propagandą lub ulec innej, silniejszej. To wszystko prowadzi krakowskiego uczonego do wniosku, że wywieranie wpływu na młodzież z myślą o długofalowych skutkach (długotrwałym przywiązaniu do idei) jest bezcelowe. Inaczej sytuacja wygląda w przypadku propagandy ukierunkowanej na chwilę obecną, która może skutkować zadowalającymi rezultatami. „W społeczeństwie pajdokratycznym zapatrywania młodzieży mogą decydować o przyszłości, ponieważ młodzież posiada możność i władzę czynu, który wykonany doraźnie, odwołać się już nie da i ciąży na dalszych losach społeczeństwa" ${ }^{51}$. Chociaż te same osoby po latach mogą krytycznie oceniać swoje działania, ich skutki często są nieodwracalne.

Jak twierdzi Koneczny, rozbieżność pomiędzy późniejszymi poglądami a przeszłymi decyzjami może mieć zgubny wpływ na sposób funkcjonowania społeczeństwa. „Pajdokracja niesie też narodowi ciężką niemoc moralną, jaką jest rozdźwięk pomiędzy zapatrywaniami a czynami”"52. Badacz dochodzi do wniosku, że niezadowolenie z siebie skutkuje negatywnymi nastrojami społecznymi („wiedzie do rozstroju, nerwozy społecznej"53), a w dalszej kolejności - zaniku kultury czynu. Działania podejmowane przez społeczeństwo są wówczas chaotyczne, nerwowe, spontaniczne (w negatywnym tego słowa znaczeniu). Nie są zaplanowane, a ich skutki są sprzeczne z zamierzonymi. „Następuje impotencja polityczna [...], ludziom opadają ręce i pozostają dwie ostateczności:

49 Ibidem, 30.

50 Ibidem, 32.

51 Ibidem, 33-34.

52 Ibidem, 34.

53 Ibidem. 
na przemian paroksyzm i apatia" ${ }^{54}$. Raz jeszcze Koneczny posiłkuje się argumentem o niekompetencji młodych, by zanegować możliwość ich aktywnego udziału (czynu) w jakiejkolwiek dziedzinie życia politycznego. Jak twierdzi, intencje nie odgrywają w tym przypadku żadnej roli. Nawet dobre zamiary młodych zostaną zniweczone z powodu braku kompetencji politycznej. Zdaniem Konecznego „czyn młodzieży - to dyletanckie eksperymentowanie, partactwo polityczne” ${ }^{\prime 5}$.

\section{Pajdokracja i apatia}

Koneczny doszukuje się popularności pajdokracji w sposobie funkcjonowania starszych pokoleń, które same w młodości angażowały się w działania polityczne. Z czasem, jak twierdzi, osoby zbyt wcześnie aktywne w życiu publicznym doświadczają wypalenia i znużenia. Ponieważ nie odczuwają dalszej satysfakcji z działalności politycznej, obarczają nią młodszych następców. Na drodze tak rozumianej transmisji pokoleniowej oraz przenoszenia odpowiedzialności na młodzież umacnia się pajdokratyczny styl funkcjonowania całego społeczeństwa. Tymczasem starsze pokolenie wpada w swoisty stupor. „Pajdokraci wyrastają bowiem $\mathrm{z}$ reguły na obojętnych widzów spraw publicznych, leniwców, którym się nie chce podjąć najmniejszego trudu"56. W opinii Konecznego zobojętnienie i marazm osób tego typu mogą zostać przerwane jedynie naciskami młodzieży. Starsi aktywizują młodych, a młodzi starszych. Błędne koło zamyka się, a pajdokracja umacnia.

Koneczny zwraca również uwagę na powszechny w społeczeństwie brak chęci działania. Chociaż „serce pragnie, żeby coś się stało" ${ }^{57}$, jest hamowane przez "mózgi, jak pola campagnii rzymskiej, zamarłe” ${ }^{\text {. }}$. Badacz dochodzi do wniosku, że wola działania nie idzie w parze z racjonalnością. $\mathrm{O}$ ile rozum cechować miałby się potrzebą systematycznych, umiarkowanych czynności, o tyle wola pragnie czynu. „A wola? Pod działaniem serca, w chwili afektu, zdobędzie się nawet na znaczny wysiłek, ale pod tym warunkiem [...], żeby to było - jednorazowo" ${ }^{59}$. Opisany rozdźwięk skutkuje, zdaniem Konecznego, niechęcią do jakiejkolwiek

54 Ibidem.

55 Ibidem, 35.

56 Ibidem, 37.

57 Ibidem.

58 Ibidem.

59 Ibidem, 38. 
aktywności wynikającej z racjonalności. Do społeczeństwa dotrze więc ten polityk, który zastosuje argumentację emocjonalną, a nie ten, który odwoła się do rozsądku. „Tak pajdokracja sprowadziła na nas zanik woli, zanik zdolności rozumowania; zrobiła z nas leniwych niedołęgów, którzy sami siebie okłamują swojem «sercem, sercem»"60.

\section{Patryjotyzm bez zajęcia}

Kolejne zagadnienie, nad którym pochyla się Koneczny, to patriotyzm. Badacz jest przekonany, że większość polskiego społeczeństwa posiada błędne wyobrażenie o tym, jak należy manifestować miłość do ojczyzny. Zdaniem historiozofa w Polsce pokutuje przekonanie, że niezbędne jest zaistnienie odpowiednich okoliczności, by móc okazać swoje przywiązanie do kraju. Co za tym idzie, młodzież poświęca duże zasoby energii na kreowanie odpowiednich warunków, a to nie przynosi większych rezultatów. W dalszej kolejności Koneczny porusza zagadnienie ignorancji, która prowadzi do braku wiedzy politycznej. Jak pisze: „Próżniactwo w zakresie teorii i próżniactwo w zakresie pracy społecznej, tak powszechne w naszym społeczeństwie, musiało zdemoralizować młodzież”61. Młodzież, która potrzebuje wzorów i „nie zniesie pustki życia”, wypełnia ją zasłyszanymi sloganami oraz frazesami, które w rzeczywistości nie niosą ze sobą żadnej wartości i treści. Z drugiej strony, jak pisze krakowski historiozof, „deklamacja polityczna toć czynność miła, nie wymagająca zmęczenia, ślęczenia, odmawiania sobie przyjemności życia. Wystarczy gadać, a [...] wyrasta się w oczach własnych i kolegów na coś wielkiego" ${ }^{2}$.

Koneczny postuluje, że jedyna możliwość zwalczania pajdokracji to zaangażowanie młodych w pracę społeczną. Uważa, że tylko te osoby, które skutecznie (!) prowadziły działalność społeczną, oświatową czy ekonomiczną, powinny mieć prawo głosu w polityce. Pozostałych określa mianem próżniaków i politycznych nieuków.

Jako próżniaków - bo przy działaniu społecznym [...], na nic deklamacja próżniacza! Jako nieuków, bo tylko praca społeczna może być odpowiednią szkołą doświadczenia i chętnych dyletantów wyrobić na znawców stosunków i warunków życia publicznego ${ }^{63}$.

60 Ibidem, 39.

61 Ibidem, 62.

62 Ibidem.

63 Ibidem, 64. 
Zdaniem Konecznego wyłącznie zaangażowanie tego typu może ukształtować właściwą formę patriotyzmu, „uczy żyć dla kraju” ${ }^{64}$. Służy wpojeniu zasady, zgodnie z którą należy nieustannie działać dla dobra wspólnego, a nie tylko sporadycznie, gdy wystąpią odpowiednie okoliczności. W końcu pomaga zrozumieć, że każda podejmowana aktywność przekłada się na „naszą siłę społeczną. Cokolwiek czynimy, wszystkiem pomagamy lub szkodzimy sprawie polskiej"65.

Nieustannie, pisze Koneczny, należy słuchać własnego sumienia patriotycznego. Niestety, jest ono zagłuszane i ignorowane, co skutkuje pajdokracją oraz polityką opierającą się na bezczynności i bezcelową, bezpłodną retoryką (i erystyką). Równocześnie, jak postuluje badacz, istnieje mnóstwo obszarów, gdzie niezbędna jest rzeczywista praca polityczna, począwszy od gospodarki i rolnictwa, a skończywszy na edukacji. Koneczny wyraża przekonanie, że młodzież chętnie zaangażowałaby się w pracę społeczną, gdyby tylko starsze pokolenia wyraziły dla niej aprobatę i dały młodym dobry przykład.

\section{Szacunku dla młodzieży}

W ostatnim $z$ analizowanych artykułów Koneczny apeluje o szacunek dla młodzieży. Uważa, że należy jej się on podobnie jak każdej innej grupie społecznej. Dopiero okazując szacunek młodszym pokoleniom, można liczyć na wzajemność w tej kwestii. Tymczasem, jak pisze krakowski badacz, „lekceważymy ją, traktując jako automat, machinę reklamową, jako bierne narzędzie, dobre do wszystkiego, które nakręcone odpowiednio, zrobi już samo więcej niż śmiałby robić sam nakręcający"66. Autor zdecydowanie przeciwstawia się instrumentalnemu wykorzystywaniu młodych. Wskazuje raz jeszcze, że politycy chcący pociągnąć za sobą młodzież nie odwołują się do rozsądku, a raczej „wyprawiają z nią [młodzieżą] istne orgie drwinek i kpinek"67. Apeluje, by chronić młodych przed wykorzystywaniem. Po raz kolejny podkreśla przyziemne motywy skłaniające pajdokratów do angażowania młodych ludzi w życie polityczne, czyli: 1) obarczanie innych własną odpowiedzialnością; 2) chęć zdobycia poparcia dla idei nieakceptowanych przez osoby dojrzałe; 3) dążenie do wykorzystania innych w charakterze tarczy w razie niepowodzenia.

\section{Ibidem.}

65 Ibidem.

66 Ibidem, 67.

67 Ibidem. 
Koneczny bardzo wysoko ceni polską młodzież. Podkreśla jej zalety, a wśród nich przede wszystkim bohaterstwo, dobrą wolę, poświęcenie i zacność. Równocześnie uważa, że cechą charakterystyczną młodości jest naiwność. Przy czym nie jest to naiwność bezgraniczna. „Nikt z młodzieży nie zapatruje się przecież na własną przyszłość, jako na nieodzowne utracenie rozumu w miarę, jak dochodzić będzie lat męskich" ${ }^{68}$. Młodzi ludzie, jak uważa Koneczny, dążą do rozwoju, dojrzałości oraz poszerzania swoich możliwości i kompetencji. Tym samym zakładają stopniowy progres, a nie regres. „I przychodzi pajdorkata [...] i śmie im mówić, że Polak jest takim jakimś specjalnym gatunkiem człowieka, który rozwija się umysłowo do nader niewielu lat, a potem rozumu mu nagle ubywa!" ${ }^{69}$. Ów pajdokrata ma świadomość, że takie rozumowanie jest nielogiczne. Jego idee nie znajdują jednak poklasku u osób dorosłych, dysponujących wiedzą i doświadczeniem, więc szuka atencji młodych. Takie postępowanie Koneczny uważa za manifestację jawnego braku szacunku dla młodzieży. Badacz wierzy, że w przyszłości młode pokolenie osiągnie samoświadomość, która pozwoli mu racjonalnie ocenić swoje możliwości i odkryć rzeczywiste intencje polityków zabiegających o jego przychylność. Pisze: „Z pochlebstwem idzie się do takich, których uważa się za głupców i którymi się w duchu gardzi" ${ }^{\prime \prime 0}$. Tymczasem, zdaniem Konecznego, młodzież bezwzględnie zasługuje na szacunek i ochronę przed siewcami pajdokracji.

\section{Podsumowanie}

Chociaż teksty Konecznego dotykające zagadnienia pajdokracji powstawały w innych realiach społeczno-kulturowych, można odnaleźć w nich wiele wątków korespondujących z czasami współczesnymi. Przede wszystkim samo zjawisko pajdokracji wydaje się nadal obecne w polskiej kulturze politycznej. Politycy chętnie zabiegają o młode pokolenia, pokazują się z nimi, oddają im głos, zachęcają do manifestacji i protestów. Podczas większości spotkań przedwyborczych i wieców zaraz za politykiem ustawiane są szeregi młodych trzymających flagi, uśmiechających się promiennie do kamer i aparatów. Tego typu obrazy wskazują na rzekome wysokie poparcie, które dany polityk ma wśród młodych pokoleń. Bardziej znamienne są jednak te sytuacje, gdy młodym

68 Ibidem, 69.

69 Ibidem, 69-70.

70 Ibidem, 71 . 
oddaje się głos w sprawach, z którymi nie są odpowiednio zaznajomieni lub nie mają wystarczającego doświadczenia życiowego, by je adekwatnie ocenić. Koronny przykład stanowi wspomniana już wcześniej Greta Thunberg. Podczas Światowego Forum Ekonomicznego w Davos z ust młodej aktywistki padły słowa: „Mówiłam rok temu, że mamy problem. Co zrobiliście? Nic. Moje pokolenie nie podda się bez walki, na was już nie liczymy"'11. Wypowiedź można sparafrazować następująco: ludzie dorośli nie sprawdzili się w kwestii ochrony klimatu, więc jedyna grupa mogąca coś zmienić to młodzież.

W złym świetle stawia dorosłych również przewodniczący Rady Dzieci i Młodzieży Rzeczypospolitej Polskiej przy Ministrze Edukacji i Nauki, Jakub Lewandowski. Szczególną popularność zyskał post w mediach społecznościowych, w którym Lewandowski nazwał polską szkołę „szczujnią na indywidualizm i różnorodność"72. Zachowanie młodego aktywisty spotkało się z jednoznaczną aprobatą mediów lewicowych. Równocześnie w mediach prorządowych pojawiły się sugestie łączące wystąpienia Lewandowskiego (dotychczas mocno związanego z prawicą) z odejściem Jarosława Gowina z rządu. Publicysta, Robert Wyrostkiewicz, w swoim artykule napisanym dla portalu „Do Rzeczy” stwierdził wprost, że ten właśnie polityk jest inspiratorem wypowiedzi i działań Lewandowskiego ${ }^{73}$.

Koneczny nie widzi miejsca w polityce na tego typu aktywność młodych. Postrzega ją jednoznacznie jako formę pajdokracji. Uważa, że polityką mają prawo zajmować się jedynie ludzie dojrzali, którzy odnieśli sukces w działalności społecznej. Te osoby powinny nieść wyłącznie na własnych barkach ciężar spoczywającej na nich odpowiedzialności, zamiast powierzać go ludziom młodszym i mniej doświadczonym. $\mathrm{W}$ tym miejscu należy postawić pytanie: czy młody wiek zawsze oznacza brak świadomości politycznej, doświadczenia i wiedzy? Wydaje się,

71 https://www.money.pl/gospodarka/greta-thunberg-w-davos-o-polskich-gornikach-6470462303762049v.html (dostęp: 14.11.2021).

72 Fragment pochodzi z wypowiedzi opublikowanej na portalu Twitter: „Polska szkoła stała się szczujnią na indywidualizm i różnorodność. Protekcjonalne podejście do kobiet, brak szacunku do jakichkolwiek mniejszości sprawia, że nie każdy dobrze się czuje w budynku, który powinno być bezpiecznym miejscem nauki. Nie ma na to zgody młodego pokolenia”. Lewandowski został zaproszony m.in. do programu „Dzień dobry TVN” oraz „Onet Rano”. Za: https://dziendobry.tvn.pl/gorace-tematy/szkola-nieprzyjazna-uczniom-jakub-lewandowski-mowi-co-nalezy-zmienic-5410528; https://wiadomosci.onet.pl/tylko-w-onecie/jakub-lewandowski-szkola-za-przemyslawa-czarnka-stala-sie-szczujnia/tgw6nct. (dostęp: 14.11.2021).

73 https://wiadomosci.onet.pl/tylko-w-onecie/jakub-lewandowski-szkola-zaprzemyslawa-czarnka-stala-sie-szczujnia/tgw6nct. (dostęp: 14.11.2021). 
że nie. Można wskazać przykłady młodych polityków, których cechuje ambicja i wysoka kompetencja polityczna. Za przykład takiej postaci media uznają Mateusza Morawieckiego, który karierę polityczną rozpoczął od sejmiku dolnośląskiego, gdy miał 30 lat ${ }^{74}$. Równocześnie dojrzali politycy, od których oczekuje się dużej odpowiedzialności i wiedzy, nie zawsze je posiadają.

Chociaż istnieją pewne wyjątki, więcej przykładów zdaje się przemawiać na korzyść tez Konecznego. W 2017 r. Eryk Mistewicz, doradca polityczny, mówił: „W Polsce polityk młodego pokolenia jest w stanie napisać jedynie tekst obrażający Jarosława Kaczyńskiego albo panegiryk na jego cześć. Gdy ma napisać o sprawie, która go interesuje, o wizji, którą chciałby zrealizować, to nie wie, co napisać” oraz „Młodzi politycy nie czytają, nie piszą, nic nie wiedzą i nie chcą się dowiedzieć"75. Uwagę zwracają również czołowi (tj. najgłośniejsi i najbardziej medialni) młodzi działacze, których uznaje się za symbol tego pokolenia polityków. Jak pisał Wiktor Świetlik:

A jak wygląda sejmowa młodzież? Symbolizuje ją posłanka Jachira, która niedawno ujawniła narodowi, że Hitler nie niszczył cmentarzy żydowskich, co świadczy o dość radykalnym niezainteresowaniu tematyką, jak na „obrończynię praw człowieka”. Jako wrocławianka pani Jachira mogłaby chociaż kojarzyć losy tamtejszego cmentarza żydowskiego przy Ślężnej, gdzie podczas wojny urządzono składnicę złomu, a planowano park miejski ${ }^{76}$.

Koneczny, doświadczony pedagog, posiadał solidne podstawy do wnioskowania o cechach młodzieży. Cechy te ujawniają się również w sposobie prowadzenia działalności politycznej przez młode pokolenia. Charakteryzuje je zazwyczaj emocjonalność i żywiołowość zwiastujące bunt. Bunt z kolei znajduje wyraz w marszach, krzyku, prowokacjach i, w końcu, specyficznym języku. Przekraczanie kolejnych granic, również tych językowych, jest przez niektórych normalizowane, a wręcz waloryzowane. Co za tym idzie, krytyka osób łamiących normy językowe i społeczne uznawana jest za „nieporozumienie i nie

74 https://zyciorysy.pl/biografia/mateusz-morawiecki/, https://www.tokfm.pl/Tokfm/ 7,102433,22409933,mlodzi-polscy-politycy-nie-czytaja-nie-pisza-nic-nie-wiedza.html (dostęp: 14.11.2021).

75 https://www.tokfm.pl/Tokfm/7,102433,22409933,mlodzi-polscy-politycy-nie-czytaja-nie-pisza-nic-nie-wiedza.html (dostęp: 14.11.2021).

76 https://wydarzenia.interia.pl/felietony/swietlik/news-tusk-moze-wrocic-bomlodosc-w-polskiej-polityce-wyglada-ponu,nId,5329935 (dostęp: 14.11.2021). 
tylko kryzys komunikacji. To zagranie niepoważne i nieadekwatne, lecz niestety skuteczne” 77 . Iwasiów pisze: „obserwujemy też dyskusję wokół tych haseł. Tę dyscyplinującą - nie wypada, tak mówi «rynsztok». [...] Moim zdaniem warte ryzyka są przejęcie, zdemontowanie tego języka i wyzwalana w tym procesie energia" ${ }^{\prime 8}$. W ten sposób cechy młodzieńczego buntu mogłyby zostać narzucone całemu społeczeństwu, a racjonalność, odpowiedzialność i wzajemny szacunek zdewaluowane jako nieznaczące, niewyzwalające energii.

Chociaż krytyka pajdokracji sformułowana przez Konecznego jest ważna, jeszcze bardziej znaczące wydają się wskazówki, które autor zawarł w swoich tekstach. By całe społeczeństwo mogło funkcjonować skutecznie, niezbędne są: 1) okazywanie młodzieży szacunku (na który zasługuje); 2) angażowanie jej w adekwatne działania (aktywność społeczną), które przygotują ją do partycypacji w życiu politycznym; 3) edukacja obywatelska i pamięć o charakterystykach tego okresu życia (bunt, naiwność, podatność na wpływ itd.). Przede wszystkim jednak młodych nigdy nie należy traktować instrumentalnie i przedmiotowo. Być może dzięki temu przyszłe elity polityczne będą odpowiedzialne, świadome, dojrzałe i racjonalne.

\section{Bibliografia}

\section{Książki i monografie}

Chodubski Andrzej, „Młodzież jako przedmiot i podmiot życia publicznego”, w Polityka młodzieżowa Unii Europejskiej, red. Maciej Boryń, Bartosz Duraj, Sylwia Mrozowska (Toruń: Wydawnictwo Adam Marszałek, 2014), 11-28.

Hajduk Barbara, Socjalizacja studentów. Badania panelowe studentów z Zielonej Góry (Warszawa: Wydawnictwo Akademickie „Żak”, 2003).

Hartmut M. Griese, Socjologiczne teorie młodzieży (Kraków: Oficyna Wydawnicza Impuls, 1996).

Iwasiów Inga, „Słowa oporu - wulgaryzmy wywrotowe”, w Język rewolucji, red.

Piotr Kosiewski (Warszawa: Fundacja im. Stefana Batorego, 2021), 19-21.

Koneczny Feliks, O pajdokracji (Warszawa: Wydawnictwo „Słowa”, 1912).

Mannheim Karl, „The problem of youth in modern society”, w Diagnosis of our time. Wartime essays of a sociologist (London: Kegan Paul, Trench, Trubner \& CO., LTD, 1943), 31-53.

77 Inga Iwasiów,„Słowa oporu - wulgaryzmy wywrotowe”, w Język rewolucji, red. Piotr Kosiewski (Warszawa: Fundacja im. Stefana Batorego, 2021), 21.

78 Ibidem, 20. 
Marzęcki Radosław, Młody obywatel we współczesnej demokracji europejskiej (Warszawa: Dom Wydawniczy ELIPSA, 2013).

Piotrowski Konrad, Tożsamość osobista w okresie wkraczania $w$ dorostość. Sytuacja młodych osób z ruchowym ograniczeniem sprawności i ich sprawnych rówieśników (Wielichowo: TIPI, 2013), 27.

Śliwerski Bogusław, „Prawo dziecka do swoich praw”, w Prawa dziecka wczoraj, dziś i jutro - perspektywa korczakowska, red. Marek Michalak (Warszawa: Biuro Rzecznika Praw Dziecka, 2018), 93-141.

Tillmann Klaus J., Teorie socjalizacji. Społeczność, instytucja, upodmiotowienie (Warszawa: Wydawnictwo Naukowe PWN, 2006).

\section{Czasopisma}

Arnett Jeffrey J., „Emerging Adulthood. A Theory of Development from the Late Teens through the Twenties", American Psychologist 55/5: 469-480.

Bartoszewicz Weronika, „Nacjonalizm na przykładzie Młodzieży Wszechpolskiej", Biuletyn Kryminologiczny 26 (2019): 161-175. https://doi.org/10.5281/ ZENODO.3751718.

Brzezińska Anna, Kaczan Radosław, Piotrowski Konrad, Rękosiewicz Małgorzata, „Odroczona dorosłość: fakt czy artefakt?”, Nauka 4 (2011): 67-107.

Dąbrowska Anna, „Zmiany obszarów podlegających tabu we współczesnej kulturze", Język a Kultura 20 (2008): 173-196.

Hildebrandt-Wypych Dobrochna, „Pokolenia młodzieży - próba konceptualizacji", Przeglad Pedagogiczny 2 (2009): 105-124.

Lubik-Reczek Natasza, „Przebudzenie młodego pokolenia. Aktywność polityczna młodzieży - studium przypadku”, Przeglad Prawa Konstytucyjnego 2 (2021): 65-77. https://doi.org/10.15804/PPK.2021.02.04.

Łukaszewicz Adam, „Kilka uwag o pisowni wyrazów greckich (i niektórych innych) w polskich tekstach dotyczących starożytności klasycznej i archeologii", Studia i Materiaty Archeologiczne 14 (2009): 105-117.

Messyasz Karolina, „Rola i znaczenie polityki w świecie młodych ludzi. Perspektywa transformacyjna", Władza Sadzenia 1: 109-136. https://doi. org/11089/1524.

Polak Ryszard, „Feliks Koneczny. Biografia uczonego”, Człowiek w Kulturze 10 (1998): 161-173.

Rokowska Anna, „Opór psychologiczny młodzieży: rola źródła i kierunku presji społecznej w kwestii ujednolicenia ubioru w szkole", Psychologia Rozwojowa 13/2 (2008): 47-56.

Slany Katarzyna, „Subwersywne zabawy Kajtusia Czarodzieja”, Pedagogika Przedszkolna $i$ Wczesnoszkolna 1/3 (2014): 103-113.

Smolík Josef, „Youth and the cult of youth?”, Kultura - Społeczeństwo - Edukacja 1/5 (2014): 203-212.

Szafraniec Krystyna, „Raz jeszcze o społecznej roli młodego pokolenia. Konteksty lokalne i globalne", Rocznik Lubuski 37/2 (2011): 11-32.

Śliwerski Bogusław, „Prawo dziecka do swoich praw”, Pedagogika Społeczna XVI/4 (2017): 37-58. 


\section{Źródła internetowe}

https:/dziendobry.tvn.pl/gorace-tematy/szkola-nieprzyjazna-uczniom-jakublewandowski-mowi-co-nalezy-zmienic-5410528 (dostęp: 14.11.2021).

https://prawo.money.pl/aktualnosci/wiadomosci/artykul/kaczynski;dosyc;szpan u;potrzebna;jest;nowa;wladza,200,0,849352.html (dostęp: 14.11.2021).

https://wiadomosci.onet.pl/tylko-w-onecie/jakub-lewandowski-szkola-

za-przemyslawa-czarnka-stala-sie-szczujnia/tgw6nct (dostęp: 14.11.2021). https://www.gov.pl/web/edukacja-i-nauka/powolano-rade-dzieci-i-mlodzie-

zy-rzeczypospolitej-polskiej-przy-ministrze-edukacji-i-nauki (dostęp: 14.11.2021).

https://www.money.pl/gospodarka/greta-thunberg-w-davos-o-polskich-gornikach-6470462303762049v.html (dostęp: 14.11.2021).

https://www.polityka.pl/tygodnikpolityka/kraj/2132068,1,zwiazki-partnerskie-

-godka-i-aborcja-tusk-i-trzaskowski-w-ogniu-pytan-od-mlodziezy.read https://www.rp.pl/polityka/art8594851-ruch-w-strone-mlodych-rafala-trzaskowskiego (dostęp: 14.11.2021).

https://www.tokfm.pl/Tokfm/7,102433,22409933,mlodzi-polscy-politycy-nie-

-czytaja-nie-pisza-nic-nie-wiedza.html (dostęp: 14.11.2021).

https://wydarzenia.interia.pl/felietony/swietlik/news-tusk-moze-wrocic-bo-

-mlodosc-w-polskiej-polityce-wyglada-ponu,nId,5329935

https://zyciorysy.pl/biografia/mateusz-morawiecki/ (dostęp: 14.11.2021).

Szafraniec Krystyna, Raport Młodzi 2011 (Warszawa: Kancelaria Prezesa Rady Ministrów, 2011). https://nck.pl/upload/attachments/302470/mlodzi_2011. pdf (dostęp: 14.11.2021).

Zarządzenie Ministra Edukacji i Nauki z dnia 7 grudnia 2020 r., https://www. infor.pl/akt-prawny/U20.2020.012.0000018,zarzadzenie-ministra-edukacji-i-nauki-w-sprawie-powolania-rady-dzieci-i-mlodziezy-rzeczypospolitej-polskiej-przy-ministrze-edukacji-i-nauki.html (dostęp: 14.11.2021). 